УДК 631.152(479.25)

(C) 2012

Бадалян М. Э., кандидат экономических наук, Казарян А. Р., кандидат экономических наук, Маргаряан М. А., соискатель

Армянский аграрный государственный университет

\title{
РОЛЬ КООПЕРАЦИИ В РАЗВИТИИ СЕЛЬСКОХОЗЯЙСТВЕННОГО ПРОИЗВОДСТВА В АРМЕНИИ
}

\author{
Рецензент - доктор экономических наук, профессор Э. С. Казарян
}

\begin{abstract}
У розвинених країнах світу кооперативи відіграють важливу роль у розвитку сільського господарства. Кооперативи сприяють раціональному використанню ресурсів, а також підвищенню ефективності виробництва. У Вірменії изей процес іде допоки поволі, шзо обумовлено недосконалістю правової сфери, низьким рівнем державного сприяння $i$ іниими чинниками. Для прискорення процесу створення сільськогосподарських кооперативів необхідно створити сприятливе середовище, прийняти Закон «Про кооперацію», прийняти державну комплексну програму сприяння, компенсувати все або частину витрат, пов'язаних із створенням кооперативів.
\end{abstract}

Ключевые слова: кооперативы, сельское хозяйство, развитие, укрупнение, благоприятная среда.

Постановка проблемы. Понятие «кооперация» в значении формы организации труда произошло от латинского слова cooperatio «сотрудничество». Кооперация создается в том случае, когда группа людей стремится выполнять взаимосвязанные процессы одного или разных типов работ, или же самодеятельные добровольные объединения мелких крестьян или ремесленников создаются для достижения общих целей в разных сферах хозяйственной деятельности. Кооперация подразумевает демократические методы управления, создается только на добровольных началах. Управленческая иерархия в истинно кооперативной системе строится снизу вверх, на принципах выборности и подотчетности перед низшими уровнями, а значит, исключает бюрократизацию аппарата. Важнейшая характеристика кооперации - постепенность выбора форм, переход от простейших к более сложным, их сосуществование и взаимное переплетение. Таким образом, она воплощает в себе то, что принято называть экономическими методами. Кооперация сельскохозяйственная способствует сплочению разрозненных крестьянских масс, содействует росту их классового самосоз- нания, выработке навыков коллективного ведения хозяйства и тем самым созданию социальноэкономических предпосылок для перехода этих стран на некапиталистический путь развития [1].

На современном этапе в развитых странах Западной Европы кооперация охватывает мелкое и среднее фермерство, мелких собственников всех отраслей реальной экономики на основе сочетания этих принципов с целью выживания. Задачами кооперации являются умелая защита от разорения и обеспечение мелкому собственнику стабильных условий для выживания в конкурентной борьбе с крупными предприятиями как внутри страны, так и на мировой арене. Цели кооперации - обеспечение возможностей использования в малом и среднем хозяйстве новаторских технологий в промышленности и индустриальных технологий в агропромышленном комплексе, направленных на рост объемов производства товаров народного потребления и устойчивых доходов кооператорам, что является залогом повышения уровня жизни населения. Поэтому кооперация, кооперативные принципы необходимы сейчас как важнейшее условие и неотъемлемая часть процесса демократизации, а на его основе - и перехода на новый уровень эффективности экономики страны.

Основные формы подобных объединений потребительские, профессиональные, кредитные, снабженческие, коммерческие и прочие кооперативы. В сельском хозяйстве кооперативы это основанные на частичном или полном обобществлении средств производства объединения сельхозпроизводителей для совместной обработки земли, использования сельскохозяйственной техники или выпуска продукции.

Кооперация - это определенная форма трудового сотрудничества людей, которая исторически существовала на ранних этапах человеческого общества. Зачатки кооперативов возникли еще в Вавилоне, Греции, Риме, Египте и т. д. В средневековье и на заре капитализма трудовое сотруд- 
ничество осуществлялось в виде организации ремесленных цехов и мануфактурных производств, а в сельском хозяйстве первичные формы кооперации были связаны с формированием общин и артелей. Сельскохозяйственная кооперация прошла трудный путь развития, в течение которого сформировала богатый опыт, разработала организационные принципы, которые с течением времени подвергались изменениям под воздействием конкретных природно-климатических условий, экономических, национальных и прочих факторов. Еще в XV веке в Северной Италии (во Флоренции) кооперативы, занимающиеся переработкой молока и реализацией сыра и масла, были освобождены от налога на землю, торговцам же было указано покупать их товар по экспортным ценам. В 1886 г. правительство поощрило создание единого органа, управляющего работой этих объединений, - лигу кооперативов Италии, которая взяла на себя все функции координации деятельностью кооперативов: от их регистрации до реализации конечного продукта [5].

В 70-е годы прошлого века в Ираке в ходе аграрных реформ вновь создаваемым кооперативам выдавался беспроцентный бюджетный кредит сроком на 30 лет и безвозмездно - техника [4].

Практически ни в одной стране Евросоюза сельскохозяйственные кооперативы не подвергаются двойному налогообложению.

В 70-е годы в Италии была принята государственная программа, предусматривающая 85процентное субсидирование расходов для создания сельскохозяйственных кооперативов. Здесь кооперативы в течение первых десяти лет полностью освобождались от уплаты налогов [3].

В Дании кооперативы вообще не облагаются налогами.

В Финляндии кооперативы играют решающую роль при разработке и реализации аграрной политики [4]. После проведения аграрных реформ, основная цель которых - внедрение разнообразных методов хозяйствования, как правило, происходит процесс укрупнения хозяйств посредством создания кооперативов, а также купли и продажи земли.

В Армении в этом направлении не была проведена активная политика, и в настоящее время действует всего около 100 кооперативов, преобладающая часть которых - потребительские. Деятельность же определенного числа кооперативов не отличается эффективностью.

Анализ основных исследований и публикации по данной проблеме. Кооперация составляет основу любого общественного строя. В насто- ящее время в мире она объединяет около 700 млн человек. В странах ЕC $46 \%$ населения состоят в кооперативах, в скандинавских странах эта цифра превышает 50 \% [4]. Еще в начале XX века вопросы совершенствования хозяйствования в аграрной сфере занимали выдающегося русского ученого А. В. Чаянова. Он придерживался мнения, что с точки зрения демократизации аграрной сферы крестьянское хозяйство наиболее предпочтительно. Одновременно эффективное хозяйствование он в основном обусловливал кооперацией, поскольку распыление средств производства (особенно земли) в конечном итоге ведет к развитию закрытого натурального хозяйства, что, бесспорно, недопустимо и опасно. Характерно и то, что в свое время А. В. Чаянов научно обосновал и доказал жизнеспособность крестьянских хозяйств, объединенных в кооперативы [8].

Идеи хозяйственной кооперации впервые были выдвинуты Р. Оуэном, А. Сен-Симоном и Ш. Фурье. Научным основам сельскохозяйственной кооперации посвящены труды всемирно признанных учёных-кооператоров русской школы: М. И. Туган-Барановского, А. В. Чаянова, Н. П. Макарова, нашедшие применение в аграрном секторе многих стран. Благодаря этим трудам Россия являлась признанным мировым центром кооперативной науки, развитие которой было подорвано с началом коллективизации в российской деревне.

Современную российскую научную школу кооперативного движения представляют такие ученые, как А. П. Макаренко, К. А. Раицкий, А. К. Семенов, А. М. Фридман, которые разрабатывали идеи кооперативного движения в период кризисной ситуации и наметили пути его дальнейшего развития в условиях экономического подъема и стабилизации темпов роста. Теоретическое обобщение начального этапа возрождения сельскохозяйственной кооперации в России отражено в работах И. Н. Буздалова, Л. В. Никифоров, Н. А. Попова, Е. В. Серовой. Возможности применения кооперативных принципов в сфере агропромышленного комплекса рассматриваются в работах таких ученых, как А.А. Апишев, В. Ф. Вершинин, А. З. Рысьмятов, А. Г. Стадник и других. Отдельные вопросы теории и практики развития современной кооперации рассмотрены в работах В.П. Василенко, А. М. Емельянова, А. В. Петрикова, А. В. Ткача, В. А. Тихонова, Г. И. Шмелева и других $[1,2]$.

В Армении вопросы теории и практики развития кооперации последные годы рассмотрены в 


\section{EKOHOMIKA}

работах С. Геворгяна, С. Аветисяна, Г. Джавадяна, Р. Саруханяна и других.

Цель исследования: выявить уровень развития и особенности форм и методов создания сельскохозяйственных кооперативов в Республике Армения.

Результаты исследования. В системе кооперации особое место принадлежит сельскохозяйственной кооперации. Последовательное претворение в жизнь ее принципов может иметь решающее значение в деле преодоления аграрного кризиса и дальнейшего развития сельского хозяйства в Республике Армения. Кооперация позволит единоличному производителю в максимальной степени использовать собственные ресурсы и получить дополнительные доходы на разных этапах процесса воспроизводства.

Сельскохозяйственные кооперативы - наиболее демократичные структуры, где в процессе объединения хозяйств не нарушаются права на собственность и участие в управлении ими. Являясь формой совместной деятельности людей и хозяйствующих субъектов, кооперация приобретает ряд преимуществ. С одной стороны, кооперация позволяет создать наиболее мощный потенциал путем объединения самостоятельно используемых ресурсов, а с другой, - даже после объединения сохранять правовую и экономическую самостоятельность участников. Эти преимущества настолько очевидны, что кооперация может стать доминирующей формой хозяйствования в аграрном секторе экономики. Подобный выбор продиктован также рядом других объективных причин: нерентабельностью деятельности крестьянских хозяйств, неудовлетворительной обеспеченностью сельхозтехникой и прочими материальными ресурсами, отсутствием рыночных инфраструктур и т.д. Сельскохозяйственная кооперация прошла непростой путь развития. Был накоплен богатый опыт, выработаны организационные принципы, которые совершенствовались в зависимости от эпохи, конкретных природно-климатических, экономических, национальных и прочих факторов.

Кооперация позволяет с максимальной эффективностью использовать имеющиеся в ее распоряжении ресурсы, усилия членов кооператива и получать дополнительную прибыль.

В основе кооперации лежат три принципа: добровольность, неприкосновенность и коллективная реализация собственности. На современном этапе в развитых странах Западной Европы кооперация охватывает мелкое и среднее фермерство, мелких собственников во всех отраслях реа- льной экономики. На основе сочетания этих принципов задачами кооперации являются умелая защита от разорения и обеспечения мелкому собственнику стабильных условий для выживания в конкурентной борьбе с крупными предприятиями как на внутреннем, так и внешнем рынке. В настоящее время в большинстве развитых стран сельскохозяйственные кооперативы это наиболее массовая экономическая организация фермеров.

Форма собственности имеет чрезвычайно важное значение для развития экономики, однако, по мнению ряда ученых, ее роль намного выше в деле повышения эффективности производства. Они считают, что вопрос эффективного хозяйствования заключается в механизмах справедливого распределения конечного продукта, правильной организации труда и производства.

В частности, доктор экономических наук Е. С. Строев пишет: «Споры о преимуществах частной или общественной форм собственности неуместны, и уже пора понять, что не может быть «эффективной» и «неэффективной» собственности». Форму собственности он причисляет к реальным категориям, а понятие эффективности в экономике относит к формам и методам хозяйствования. По его мнению, «эффективное хозяйствование» - это естественная категория, а «эффективная собственность» - иррациональная [7].

В результате начатых в 1991 г. реформ в аграрной сфере экономики Республики Армения стали зарождаться присущие рыночному хозяйству элементы свободных экономических отношений, возникли новые конкурентные формы собственности на землю и средства производства. В процессе преобразований были ликвидированы прежние формы хозяйствования - коллективные и советские хозяйства, владеющие крупным механизированным производством. На смену им пришли небольшие крестьянские хозяйства, где довольно сложно организовать высокоэффективное товарное производство. Весь земельный фонд республики сосредоточен на 173000 участках. В результате приватизации земли они еще больше расчленились, и теперь на долю одного крестьянского хозяйства приходится 1,4 га сельхозугодий, в том числе 1,1 га пашни. Если принять во внимание, что земельный надел крестьянского хозяйства состоит из 4-5-ти участков, то в настоящее время земледелие ведется на 1,3 млн небольших участках, а в подобных условиях весьма проблематичны эффективность производства и организации труда. Предполага- 
лось, что на следующем этапе аграрных преобразований в Республике Армения должны были быть усовершенствованы формы хозяйствования, увеличены размеры хозяйств, разработаны и реализованы основополагающие принципы государственного регулирования сельского хозяйства, однако на деле реформы в РА ограничились лишь приватизацией.

В мировой практике существует два способа укрупнения производства:

- увеличение размеров фермерских хозяйств путем купли и продажи земли, т. е. создания рынка земли;

- создание кооперативов.

Исходя из почвенно-климатических условий, особенностей экономического развития, социального обеспечения крестьян, национального менталитета и пр., в Армении целесообразна кооперативная форма укрупнения производства, которая имеет ряд преимуществ.

Сельскохозяйственные кооперативы - это структуры, в которых при объединении не нарушаются имущественные права крестьянских хозяйств и право на участие в управлении хозяйством.

По нашему мнению, в настоящее время в РА кооперированию в сельскохозяйственной сфере и укрупнению крестьянских хозяйств мешает ряд факторов, в частности:

- отсутствие действенного и гибкого рынка земли. Это препятствует сосредоточению земли в руках наиболее деятельных и предприимчивых людей, которые в состоянии использовать ее с наибольшей эффективностью;

- несовершенство правового поля;

- низкий уровень развития инфраструктур;

- несовершенство механизмов государственного содействия;

- неудовлетворительная работа консультационных и информационных служб (пассивность в деле популяризации преимуществ подобной формы хозяйствования);

- слабая обеспеченность сельскохозяйственной сферы финансовыми и прочими ресурсами;

- высокие налоги и т. д.

Создание кооперативов в аграрной сфере имеет стратегическое значение для государства, поскольку будет содействовать решению проблем продовольственной безопасности страны, занятости сельского населения и целого ряда социальных задач.

Исходя из основных принципов организации кооперативов, следует предположить, что подобная форма хозяйствования создает крестьянс- ким хозяйствам все условия для свободы действий в решении экономических и социальных задач, а также проблем, касающихся собственности.

Поспешность в проведении реформ, несовершенство правового поля и игнорирование международного опыта не позволили выбрать такие формы хозяйствования, которые были бы более эффективными. Взамен конкурентоспособной системы хозяйствования сформировалась монополия крестьянских хозяйств, которые используют около $96 \%$ приватизированных земель. Вызывают серьезную озабоченность и малые размеры крестьянских хозяйств.

Аграрная политика государства должна быть направлена на рациональное сочетание мелкого, среднего и крупного хозяйств, при ведущей роли крупных хозяйств; на государственное регулирование и поддержку аграрного сектора. Государственное содействие кооперации в сфере сельского хозяйства в основном должно быть направлено на создание благоприятных условий для ее эффективной деятельности.

Для поощрения создания кооперативов как эффективной формы хозяйствования, по нашему мнению, будет целесообразно реализовать следующие меры:

- предоставлять субсидии из госбюджета для погашения части процентных ставок кредитов коммерческих банков;

- договоры на госзакупки в порядке приоритетности заключать с кооперативами;

- на ближайшие несколько лет для кооперативов установить сравнительно низкую плату за использование пахотных земель государственного резервного фонда;

- на ближайшие 5 лет для кооперативов установить ставку налога на прибыль на 50 \% ниже;

- создать льготные условия в вопросе использования местного сырья и ресурсов;

- субсидировать из госбюджета часть страховых выплат кооперативов;

- предоставлять бесплатную официальную информацию о внутренних и внешних рынках сбыта;

- для кооперативов, осуществляющих импорт техники и технологий, установить низкие или нулевые таможенные пошлины.

Для повышения эффективности функционирования сельскохозяйственных кооперативов необходимо формирование хозяйств оптимального размера и оптимизации размеров земельных угодий реформируемых предприятий. Крупное сельскохозяйственное производство, 
как правило, имеет преимущества перед мелким, прежде всего, в обеспечении техникой, а также в организации сбыта произведенной сельскохозяйственной продукции.

Выводы. Совершенствование форм хозяйствования, по нашему мнению, должно идти по пути оптимизации размеров фермерских хозяйств и создания сельскохозяйственных кооперативов. Одновременно очень важно усовершенствовать и арендные отношения, которые будут способствовать увеличению размеров хозяйств. Процесс укрупнения аграрного производства неизбежен, и подобная тенденция наблюдается почти во всех странах мира. Опыт показывает, что сравнительно крупные хозяйства более конкурентоспособны и всегда выделялись высокой товарностью и уровнем производительности труда, отдачей капитальных вложений и эффективностью использования средств производства.

С целью осуществления комплексного развития создания правовых, экономических и организационных условий эффективного функционирования сельскохозяйственных кооперативов рекомендуется разработать и принять Программу развития сельскохозяйственной кооперации в Республике Армения, основная цель которой обеспечение устойчивого развития кооперативного сектора, повышение ее роли в стабилизации АПК, защита экономических интересов сельскохозяйственных товаропроизводителей.

С учетом наличия специфических особенностей каждого (марза) региона рекомендуется раз-

\section{БИБЛИОГРАФИЯ}

1. Геворкян C. A. Сельскохозяйственная кооперация. - Ереван, 2002. - С. 35-42. (На арм. языке).

2. Манасерян Н. Аграрный вопрос вчера и сегодня. - Ереван, 2006. - С. 24-31. (На арм. языке) 3. Наумов В. К. Кооперация в Италии. - М. : Эксмо, 1989. - С. 64-78.

4. Серова E. B. Аграрная экономика. - М., 1999. - C. 74-83.

5. Тарасов Н., Володин В. Объединение сельскохозяйственных кооперативов (кооперация или интеграция) // Экономика и управление АПК. - работать Региональные программы развития сельскохозяйственной кооперации, которые будут включать разъяснительную работу, оказывающих финансовую, организационную, производственную, пропагандистскую, консультационную, информационную, практическую помощь созданным кооперативам. Разработка комплексных целевых государственных и региональных программ развития сельскохозяйственной кооперации представляет собой комплекс взаимосвязанных задач, адресных мероприятий социального, экономического, организационного, производственного характера с указанием использованных ресурсов, источников их получения, достигаемых результатов и механизм распространения и развития сельскохозяйственной кооперации в РА. Региональные программы по организации сельских потребительских кооперативов будут способствовать ускорению процесса создания, распространения положительного опыта, облегчению доступа малых форм хозяйствования к рынкам сбыта, снабжению материально-техническими ресурсами, выполнению агросервисных услуг. Наличие конкретных карт по организации СПК в разрезе регионов даст возможность выявления ресурсного потенциала имеющихся предприятий, возможность организации и размещения различных моделей СПК, определить степень удовлетворения потребностей в них, доступности к рынкам сбыта, снабжения, оценить перспективы развития и их влияние на экономику региона.

2001. - № 4. - С. 57-64.

6. Федеральный закон РФ «О крестьянских (фермерских) хозяйствах», 2003. - С. 56-73.

7. Хоныкин B. Земельная собственность и предпринимательский менеджмент / Международный сельскохозяйственный журнал. - 2001. № 4. - C. 40-43.

8. Чаянов $A$. B. О сельскохозяйственной кооперации. - Саратов: Приволжское книжное издательство, 1989. - С. 56-64. 